AperTO - Archivio Istituzionale Open Access dell'Università di Torino

New human fossil from the latest Pleistocene levels of Grotta Romanelli (Apulia, southern Italy)

This is a pre print version of the following article:

Original Citation:

Availability:

This version is available http://hdl.handle.net/2318/1832348

since 2022-01-14T11:38:24Z

Published version:

DOI:10.1007/s12520-021-01491-1

Terms of use:

Open Access

Anyone can freely access the full text of works made available as "Open Access". Works made available under a Creative Commons license can be used according to the terms and conditions of said license. Use of all other works requires consent of the right holder (author or publisher) if not exempted from copyright protection by the applicable law. 


\section{Metadata of the article that will be visualized in OnlineFirst}

\begin{tabular}{|c|c|c|}
\hline ArticleTitle & \multicolumn{2}{|c|}{ New human fossil from the latest Pleistocene levels of Grotta Romanelli (Apulia, southern Italy) } \\
\hline \multicolumn{3}{|l|}{ Article Sub-Title } \\
\hline Article CopyRight & \multicolumn{2}{|c|}{$\begin{array}{l}\text { The Author(s), under exclusive licence to Springer-Verlag GmbH Germany, part of Springer Nature } \\
\text { (This will be the copyright line in the final PDF) }\end{array}$} \\
\hline Journal Name & \multicolumn{2}{|c|}{ Archaeological and Anthropological Sciences } \\
\hline \multirow[t]{12}{*}{ Corresponding Author } & FamilyName & Iannucci \\
\hline & Particle & \\
\hline & Given Name & Alessio \\
\hline & Suffix & \\
\hline & Division & Dipartimento di Scienze della Terra, Sapienza \\
\hline & Organization & Università di Roma \\
\hline & Address & Roma, 00185, Italia \\
\hline & Phone & \\
\hline & Fax & \\
\hline & Email & alessio.iannucci@uniroma1.it \\
\hline & URL & \\
\hline & ORCID & http://orcid.org/0000-0002-4392-5690 \\
\hline \multirow[t]{12}{*}{ Author } & FamilyName & Mecozzi \\
\hline & Particle & \\
\hline & Given Name & Beniamino \\
\hline & Suffix & \\
\hline & Division & Dipartimento di Scienze della Terra, Sapienza \\
\hline & Organization & Università di Roma \\
\hline & Address & Roma, 00185, Italia \\
\hline & Phone & \\
\hline & Fax & \\
\hline & Email & \\
\hline & URL & \\
\hline & ORCID & http://orcid.org/0000-0002-7097-3217 \\
\hline \multirow[t]{12}{*}{ Author } & FamilyName & Buzi \\
\hline & Particle & \\
\hline & Given Name & Costantino \\
\hline & Suffix & \\
\hline & Division & DFG Center for Advanced Studies "Words, Bones, Genes, Tools" \\
\hline & Organization & Eberhard Karls Universität Tübingen \\
\hline & Address & 72070, Tübingen, Germany \\
\hline & Phone & \\
\hline & Fax & \\
\hline & Email & \\
\hline & URL & \\
\hline & ORCID & http://orcid.org/0000-0001-8951-2990 \\
\hline \multirow[t]{6}{*}{ Author } & FamilyName & Micarelli \\
\hline & Particle & \\
\hline & Given Name & Ileana \\
\hline & Suffix & \\
\hline & Division & Dipartimento di Biologia Ambientale, Sapienza \\
\hline & Organization & Università di Roma \\
\hline
\end{tabular}




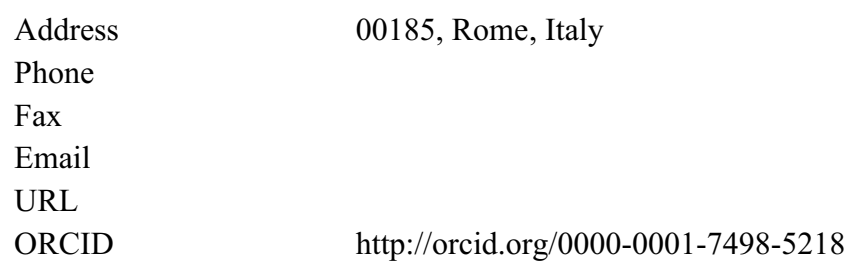

\begin{tabular}{|c|c|c|}
\hline \multirow[t]{12}{*}{ Author } & FamilyName & Bona \\
\hline & Particle & \\
\hline & Given Name & Fabio \\
\hline & Suffix & \\
\hline & Division & \\
\hline & Organization & Museo Civico dei Fossili di Besano \\
\hline & Address & Via Prestini 5, 21050, Besano, Italy \\
\hline & Phone & \\
\hline & Fax & \\
\hline & Email & \\
\hline & URL & \\
\hline & ORCID & http://orcid.org/0000-0003-4994-7003 \\
\hline \multirow[t]{15}{*}{ Author } & FamilyName & Forti \\
\hline & Particle & \\
\hline & Given Name & Luca \\
\hline & Suffix & \\
\hline & Division & Dipartimento Di Scienze Della Terra "Ardito Desio" \\
\hline & Organization & Università Degli Studi di Milano \\
\hline & Address & 20133, Milan, Italy \\
\hline & Division & \\
\hline & Organization & $\begin{array}{l}\text { Consiglio Nazionale delle Ricerche Di Italia (CNR), Istituto di Geoscienze e } \\
\text { Georisorse }\end{array}$ \\
\hline & Address & 56124, Pisa, Italy \\
\hline & Phone & \\
\hline & Fax & \\
\hline & Email & \\
\hline & URL & \\
\hline & ORCID & http://orcid.org/0000-0002-5662-7756 \\
\hline \multirow[t]{12}{*}{ Author } & FamilyName & Lembo \\
\hline & Particle & \\
\hline & Given Name & Giuseppe \\
\hline & Suffix & \\
\hline & Division & \\
\hline & Organization & Ministero dell'Istruzione \\
\hline & Address & 44121, Ferrara, Italy \\
\hline & Phone & \\
\hline & Fax & \\
\hline & Email & \\
\hline & URL & \\
\hline & ORCID & http://orcid.org/0000-0001-9367-6509 \\
\hline \multirow[t]{8}{*}{ Author } & FamilyName & Manzi \\
\hline & Particle & \\
\hline & Given Name & Giorgio \\
\hline & Suffix & \\
\hline & Division & Dipartimento di Biologia Ambientale, Sapienza \\
\hline & Organization & Università di Roma \\
\hline & Address & 00185, Rome, Italy \\
\hline & Phone & \\
\hline
\end{tabular}


Fax

Email

URL

ORCID http://orcid.org/0000-0002-8611-1371

\begin{tabular}{|c|c|c|}
\hline \multirow[t]{12}{*}{ Author } & FamilyName & Mazzini \\
\hline & Particle & \\
\hline & Given Name & Ilaria \\
\hline & Suffix & \\
\hline & Division & Consiglio Nazionale delle Ricerche di Italia (CNR) \\
\hline & Organization & Istituto di Geologia Ambientale and Geoingegneria \\
\hline & Address & Monterotondo, 00015, Rome, Italy \\
\hline & Phone & \\
\hline & Fax & \\
\hline & Email & \\
\hline & URL & \\
\hline & ORCID & http://orcid.org/0000-0003-2164-7826 \\
\hline \multirow[t]{12}{*}{ Author } & FamilyName & Muttillo \\
\hline & Particle & \\
\hline & Given Name & Brunella \\
\hline & Suffix & \\
\hline & Division & Dipartimento degli Studi Umanistici \\
\hline & Organization & Università di Ferrara \\
\hline & Address & 44121, Ferrara, Italy \\
\hline & Phone & \\
\hline & Fax & \\
\hline & Email & \\
\hline & URL & \\
\hline & ORCID & http://orcid.org/0000-0001-8039-5767 \\
\hline \multirow[t]{12}{*}{ Author } & FamilyName & Pieruccini \\
\hline & Particle & \\
\hline & Given Name & Pierluigi \\
\hline & Suffix & \\
\hline & Division & Dipartimento di Scienze della Terra \\
\hline & Organization & Università di Torino \\
\hline & Address & 10125, Torino, Italy \\
\hline & Phone & \\
\hline & Fax & \\
\hline & Email & \\
\hline & URL & \\
\hline & ORCID & http://orcid.org/0000-0002-8994-2867 \\
\hline \multirow[t]{12}{*}{ Author } & FamilyName & Ranaldo \\
\hline & Particle & \\
\hline & Given Name & Filomena \\
\hline & Suffix & \\
\hline & Division & \\
\hline & Organization & Museo della Preistoria di Nardò \\
\hline & Address & 73048, Lecce, Italy \\
\hline & Phone & \\
\hline & Fax & \\
\hline & Email & \\
\hline & URL & \\
\hline & ORCID & http://orcid.org/0000-0001-9885-5717 \\
\hline
\end{tabular}


Bartichl'same Dario

Suffix

Division Dipartimento degli Studi Umanistici

Organization

Address

Division

Organization

Address

Università di Ferrara

44121, Ferrara, Italy

Geosciences Center

University of Coimbra

Phone

Fax

Email

URL

ORCID

http://orcid.org/0000-0002-7427-0877

\section{Sardella}

Raffaele

Dipartimento di Scienze della Terra, Sapienza

Università di Roma

Roma, 00185, Italia

Address

Phone

Fax

Email

URL

ORCID

http://orcid.org/0000-0002-9752-6281

\begin{tabular}{lll}
\hline Schedule & $\begin{array}{l}\text { Received } \\
\text { Revised } \\
\text { Accepted }\end{array}$ & 4 May 2021 \\
& 12 Dec 2021
\end{tabular}

Abstract

Grotta Romanelli can be counted among the most interesting sites for the late Upper Palaeolithic of the Mediterranean area, since returned a consistent record of lithic artefacts, faunal remains, mobiliary and parietal art, and human fossils which represent the least-known materials from the context. The resumption of the investigations in 2015, after 40 years of inactivity in the cave, provided relevant results. During the 2019 campaign, a distal phalanx of the hand was recovered in the so-called terre brune levels, providing for the first time a clear stratigraphic and chronological reference for the human fossils record of Grotta Romanelli. In addition to morphological description and age estimation, the new finding is here analyzed using 3D Micro-CT scans. The new human fossil confirms the exceptional richness of the paleoanthropological record of Grotta Romanelli, opening new avenues of investigation and posing crucial questions on the use of the cave and cultural practices at the Late PleistoceneHolocene boundary.

Keywords (separated by '-') Homo sapiens - Distal phalanx of the hand - Morphology - Upper Palaeolithic - Final Epigravettian

Footnote Information

The online version contains supplementary material available at https://doi.org/10.1007/s12520-02101491-1. 


\title{
2 New human fossil from the latest Pleistocene levels of Grotta 3 Romanelli (Apulia, southern Italy)
}

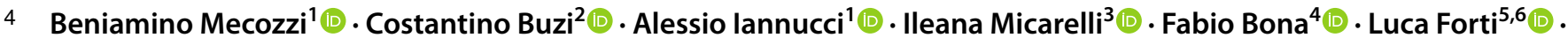

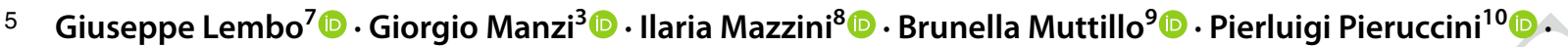

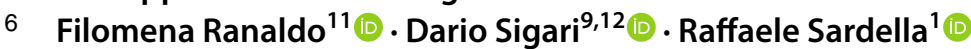

7 Received: 4 May 2021 / Accepted: 12 December 2021

8 ( The Author(s), under exclusive licence to Springer-Verlag GmbH Germany, part of Springer Nature 2021

\section{QQ1 Abstract}

10 Grotta Romanelli can be counted among the most interesting sites for the late Upper Palaeolithic of the Mediterranean area,

11 since returned a consistent record of lithic artefacts, faunal remains, mobiliary and parietal art, and human fossils which

12 represent the least-known materials from the context. The resumption of the investigations in 2015 , after 40 years of inactivity

13 in the cave, provided relevant results. During the 2019 campaign, a distal phalanx of the hand was recovered in the so-called

14 terre brune levels, providing for the first time a clear stratigraphic and chronological reference for the human fossils record

15 of Grotta Romanelli. In addition to morphological description and age estimation, the new finding is here analyzed using

16 3D Micro-CT scans. The new human fossil confirms the exceptional richness of the paleoanthropological record of Grotta

17 Romanelli, opening new avenues of investigation and posing crucial questions on the use of the cave and cultural practices

18 at the Late Pleistocene-Holocene boundary.

AQ2 Keywords Homo sapiens · Distal phalanx of the hand · Morphology $\cdot$ Upper Palaeolithic $\cdot$ Final Epigravettian

\section{Introduction}

One of the richest human records in the Italian Peninsula comes from Grotta Romanelli (GR) (Sardella et al. 2018, 2019; Fig. 1), in the Apulia region (SM 1). This cave has been excavated since the beginning of 1900 and the paleoanthropological record includes three burials, cranial remains, mandibles, isolated teeth, and postcranial elements (SM 2 and 2.1). After 40 years from the latest campaign, in 2015, new fieldwork and excavations started in the site, thanks to a project supported by Sapienza University of Rome. During the new excavations, a human bone was found in the upper part of the sedimentary succession, generally known as terre brune. This new human finding, a distal phalanx of the hand, has been studied through the use of Micro-CT imaging and is here described together with its stratigraphic context and a chronological assessment (SM 2.2 and 2.3).
Alessio Iannucci

alessio.iannucci@uniroma1.it

1 Dipartimento di Scienze della Terra, Sapienza, Università di Roma, Roma 00185, Italia

2 DFG Center for Advanced Studies "Words, Bones, Genes, Tools", Eberhard Karls Universität Tübingen, 72070 Tübingen, Germany

3 Dipartimento di Biologia Ambientale, Sapienza, Università di Roma, 00185 Rome, Italy

4 Museo Civico dei Fossili di Besano, Via Prestini 5, 21050 Besano, Italy

5 Dipartimento Di Scienze Della Terra "Ardito Desio", Università Degli Studi di Milano, 20133 Milan, Italy
6 Consiglio Nazionale delle Ricerche Di Italia (CNR), Istituto di Geoscienze e Georisorse, 56124 Pisa, Italy

7 Ministero dell'Istruzione, 44121 Ferrara, Italy

8 Consiglio Nazionale delle Ricerche di Italia (CNR), Istituto di Geologia Ambientale and Geoingegneria, Monterotondo, 00015 Rome, Italy

9 Dipartimento degli Studi Umanistici, Università di Ferrara, 44121 Ferrara, Italy

10 Dipartimento di Scienze della Terra, Università di Torino, 10125 Torino, Italy

11 Museo della Preistoria di Nardò, 73048 Lecce, Italy

12 Geosciences Center, University of Coimbra, Coimbra 3030-790, Portugal

\begin{tabular}{|l|l|l|l|l|}
\hline Journal : Large 12520 & Article No : 1491 & Pages : 4 & MS Code : 1491 & Dispatch : 3-1-2022 \\
\hline
\end{tabular}


Fig. 1 Geographic position of Grotta Romanelli (a); photo of the Romanelli bay (b, modified from Forti et al. 2020); sedimentary succession of SS3 (c) and its stratigraphic $\log (\mathbf{d})$. Superior view of the digital model of the human phalanx RR1127 (center), reconstructed from microCT-scan. In different colors are reported two coronal sections, one near de distal end (upper left, green) and the other at the proximal end (lower left, yellow). In red is reported a mid-sagittal section (right) (e). RR1127 from Grotta Romanelli (f) in proximal (f1), distal (f2), anterior (f3), dorsal (f4), lateral (f5), and medial (f6) views
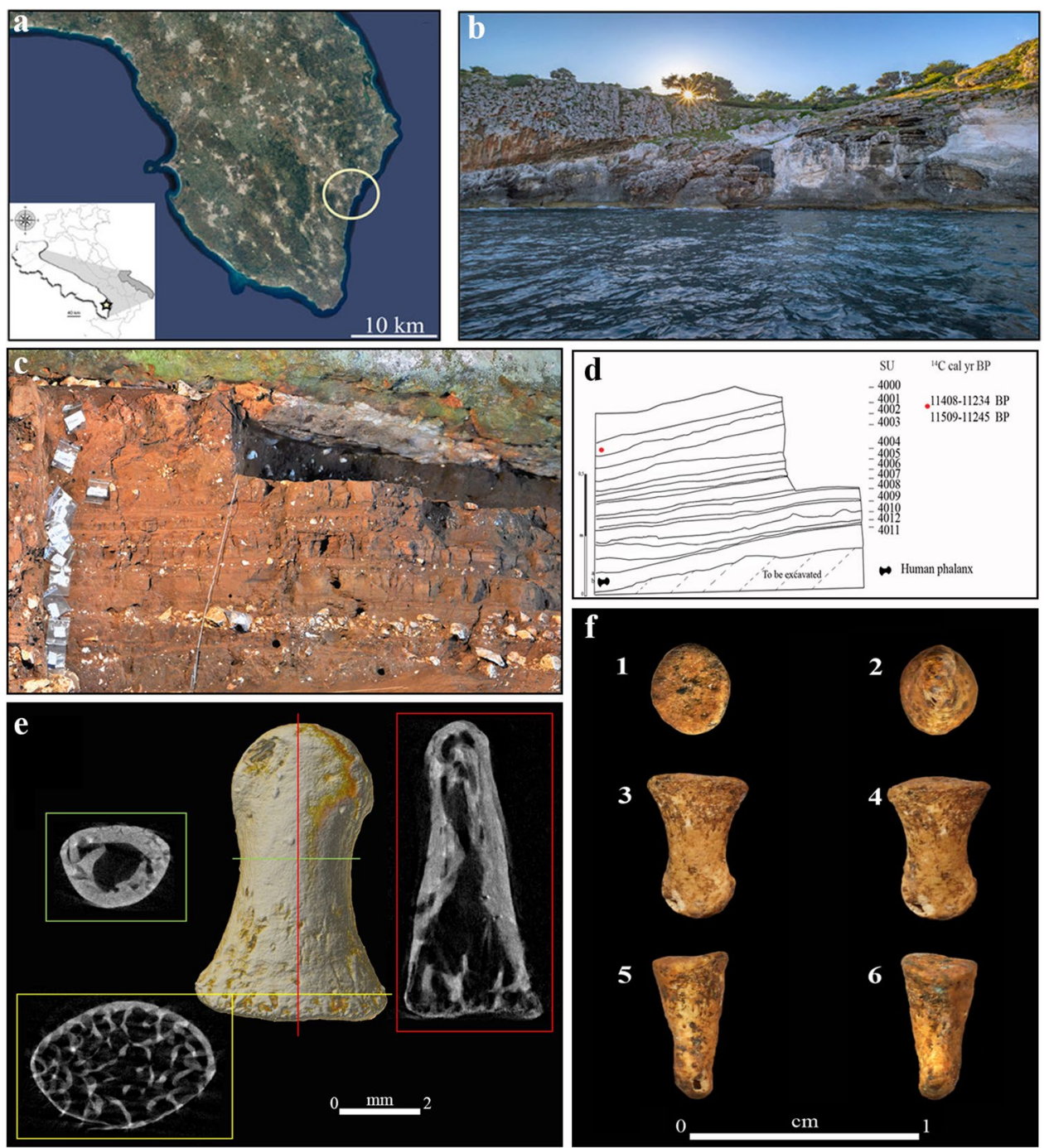

\section{The new human remain from Grotta Romanelli}

The distal phalanx of the hand, labeled with the catalog number RR1127, was found during the 2019 fieldwork activities and it is temporarily housed in the PaleoFactory Laboratory, Department of Earth Sciences, Sapienza, University of Rome.

RR1127 (Fig. 1) is a small tubular extremity bone from a human individual. The specimen is almost complete, missing a portion of the distal portion $(1 \times 1.5 \mathrm{~mm})$. The maximum length of the fragment, from the double proximal facet up to opposite tip, is $7.8 \mathrm{~mm}$ (Table 1).

The phalanx is flattened on the palmar surface and rounded dorsally, showing a D-shaped appearance in the cross-section of the shaft. This morphology characterizes it as a hand phalanx. Furthermore, its tapering shape indicates that the phalanx is a distal one, although lacking a hypertrophied ungual tuberosity.

The process of fusion between distal epiphyses of phalanges and the shafts starts around 13.5 years old in females and 16 years old in males (Schaefer et al. 2009). On the proximal facet, signs of bony activity that may suggest the start or the

Table 1 Measurements of RR1127 from Grotta Romanelli

\begin{tabular}{ll}
\hline Measurements & $\mathrm{mm}$ \\
\hline Maximum length (ML) & 7.8 \\
Midshaft breadth (MB) & 2.8 \\
Midshaft height (MH) & 2 \\
Proximal breadth (PB) & 4.5 \\
Distal breadth (DB) & 3.3 \\
Distal height (DH) & 2 \\
Proximal height (PH) & 3.5 \\
\hline
\end{tabular}

\begin{tabular}{|l|l|l|l|l|}
\hline Journal : Large 12520 & Article No : 1491 & Pages : 4 & MS Code : 1491 & Dispatch : 3-1-2022 \\
\hline
\end{tabular}


continuing of the processes of epiphyseal fusion are not visible. In Fig. 1 (yellow box), where it is reported the coronal section of the proximal end, it is evident the starting of that process, called billowing (White et al. 2011). This evidence, very common on the epiphyses of sub-adults, is characterized by an undulated surface. Even if the billowing is not visible on the proximal articular surface of the specimen (Fig. 1), the beginning of this process is well detachable from the inner view.

Given the juvenile age of the individual, it is not possible to distinguish to which finger it belongs. As well, any degenerative process of the joint is not noticeable. In addition, the phalanx does not show any concavity or marked bony characteristics related to stress. This evidence allows classifying the individual as a sub-adult. The possible young age is further corroborated by the lack of a well-developed ungual tuberosity.

In literature, most of the analyzed findings of fossil phalanges are from adult individuals (for a complete review of the specimens, see Lorenzo et al. 2015). A comparison with modern cases of human sub-adults (Gaskin et al. 2011) suggests that the individual belongs to the group of children (3-12 years old, following age subdivision in Buikstra and Ubelaker 1994).

\section{Discussion and conclusion}

The juvenile distal phalanx of the hand here described is the first human remain from GR, precisely contextualized in situ, that is chronologically attributed to the final Late Pleistocene (for a complete review of the human fossil record from GR, see Supplementary Materials 2.1). In fact, the stratigraphic provenance and chronology of the human fossils collected in the first half of 1900 during the excavations by Gian Alberto Blanc (Blanc 1920, 1928) are still poorly constrained. Other human materials recovered by Paolo Emilio Stasi in the early years of 1900 (Stasi and Regalìa 1904) are shrouded by even more uncertainty.

Therefore, the newly discovered human phalanx RR1127 confirms that human frequentation occurred in the cave in the latest Pleistocene levels, between 13,886-13,589 and 11,319-11,188 cal. years BP. However, SS3 succession, which enclosed the human finding, is characterized by several erosional surfaces, like that recognized at the base of SU 4011 and sedimentary structures (i.e., SU 4011a), that suggest the presence of runoff processes within the cave (SM 4). Taphonomic and stratigraphical analyses show the impact of water flows in the deposition of fossils within the sedimentary succession in the cave, especially during the formation of the terre brune deposit (SM 2.3 and 4). This may explain why the RR1127 was found isolated and disarticulated in the inner chamber of GR.
From a social perspective (SM 5), RR1127 suggests that the access to the cave was probably not limited upon an age-based distinction of the members of the human group and fixes new research questions for the future: (i) Was GR used as a burial ground? (ii) Did the use of the cave change over time, i.e., from a living area to a burial ground or wice versa? (iii) What was the role of young individuals in the Upper Paleolithic societies, since the consistent number of juvenile individuals in late Upper Paleolithic burials? (iv) Is there any specific area of GR where people were laid down or buried? (v) Is there any specific association between the human remains and the parietal art in GR?

The discovery of a human bone during the new excavation campaigns confirms the richness of the paleoanthropological heritage of GR and reveals that is paramount to conduct further research in this renowned site, where much has yet to be discovered. New human findings from GR can add crucial elements in the contextualization of the human occupation of the cave and its use. The detailed and thorough contextualization of new findings (i.e., mineralogical, isotopic and paleobotanical analyses, study of vertebrate remains, lithic artefacts, and mobiliary art) can enrich the knowledge on the European-western Asian Late Pleistocene framework. In the future, historical collections from GR should be revised to better define their morphological and biometric variability, their stratigraphic provenance (if possible), the exact number of the remains for each level (as defined by Blanc 1920), the ration of adult and juvenile individuals, and, in the case of burials, the demography.

Last, the RR1127 human phalanx shows how even a small finding may determine a new push in the research by opening new questions and provide important information in the understanding of an overlooked site.

Supplementary Information The online version contains supplementary material available at https://doi.org/10.1007/s12520-021-01491-1.

Acknowledgements The authors are thankful to the Soprintendenza Archeologia, Belle Arti e Paesaggio delle province di Brindisi, Lecce e Taranto (Maria Piccarreta, Laura Masiello and Serena Strafella) for authorizing the research and field activities (2015-2017 and 20182020, resp. R. Sardella). We are grateful to Castro municipality, the Capitanerie di Porto di Castro e di Otranto and Parco Naturale Regionale Costa Otranto S.M. di Leuca-Bosco di Tricase. We thank Medica Assunta Orlando (Museo Civico di Paleontologia e Paletnologia, Maglie), Francesca Alhaique and Luca Bondioli (Museo delle Civiltà, ex. Museo Nazionale Preistorico ed Etnografico L. Pigorini, Roma), Dario Massafra (Museo della Preistoria, Nardò), Luciano Bruni, and Stefano Grimaldi (Istituto Italiano di Paleontologia Umana, IsIPU) for their assistance in locating the archaeological and palaeontological material from Grotta Romanelli and the opportunity to study it. We also thank Rossella Bedini e Raffaella Pecci (Centro Nazionale di Tecnologie Innovative in Sanità Pubblica-Istituto Superiore di Sanità) for the digital acquisition of the human phalanx. Many colleagues helped during the 2015 fieldwork: Luca Bellucci, Andrea Billi, Mauro Brilli, Jacopo Conti, Giovanni Gaglianone, Francesca Giustini, Dawid 
Adam Iurino, and Flavia Strani. We want to thank Ninì Ciccarese, Toto De Santis, Don Piero Frisullo, Luigi Fersini, Antonio Capraro, and Michele Rizzo for their continuous and precious logistic support. We also wish to thank all members of the Romanelli team and Gruppo Speleologico Salentino for their useful suggestions and help.

Funding This work was supported by Grandi Scavi 2016 (ref. SA116154CD9592F3), Grandi Scavi 2017 (ref. SA11715C81468801), Grandi Scavi 2018 (ref. SA1181642D3B3C58), Grandi Scavi 2019 (ref. SA11916B513E7C4B), and Grandi Scavi 2020 (ref. SA120172B2C05E68) of Sapienza, University of Rome, resp. Raffaele Sardella.

Data availability Not applicable.

Code availability (software application or custom code) Not applicable.

\section{Declarations}

Competing interests The authors declare no competing interests.

\section{References}

Blanc GA (1920) Grotta Romanelli I. Stratigrafia dei depositi e natura e origine di essi. Archivio per L'antropologia e La Etnologia 50:1-39

Buikstra JE, Ubelaker DH (1994) Standard for data collection from human skeletal remains. Arkansas Archaeological Survey Research Series, 40, Fayetteville

Forti L, Mazzini I, Mecozzi B, Sigari D, Sardella R (2020) Grotta Romanelli (Castro, Lecce) un sito chiave del Quaternario mediterraneo. Geologicamente 2:18-27. https://doi.org/10.3301/ GM.2020.02

Gaskin CM, Kahn MMSL, Bertozzi JC, Bunch PM (2011) Skeletal development of the hand and wrist: a radiographic atlas and digital bone age companion. Oxford University Press, Oxford

Lorenzo C, Pablos A, Carretero JM, Huguet R, Valverdú J, MartinónTorres M, Arsuaga LL, Eudald Carbonell E, de Castro JMB (2015) Early Pleistocene human hand phalanx from the Sima del Elefante (TE) cave site in Sierra de Atapuerca (Spain). J Human Evol 78:114-121

Sardella R, Mazzini I, Giustini F, Mecozzi B, Brilli M, Iurino DA, Lembo G, Muttillo B, Massussi M, Sigari D, Tucci S, Voltaggio M (2018) Grotta Romanelli (Southern Italy, Apulia): legacies and issues in excavating a key site for the Pleistocene of the Mediterranean. Riv Ital Paleontolog Stratigr 124(2):247-264. https://doi. org/10.13130/2039-4942/9983

Sardella R, Iurino DA, Mecozzi B, Sigari D, Bona F, Bellucci L, Coltorti M, Conti J, Lembo G, Muttillo B, Mazzini I (2019) Grotta Romanelli (Lecce, Southern Italy) Between past and future: new studies and perspectives for an archaeo-geosite symbol of the palaeolithic in Europe. Geoheritage 11:1413-1432

Schaefer M, Black SM, Schaefer MC, Scheuer L (2009) Juvenile osteology. Academic Press, San Diego

Stasi PE, Regalìa E (1904) Grotta Romanelli stazione con faune interglaciali calde e di steppa. Nota preventiva. Società Italiana di Antropologia 1:17-81

White TD, Black MT, Folkens PA (2011) Human osteology. Academic press, Burlington

Publisher's note Springer Nature remains neutral with regard to jurisdictional claims in published maps and institutional affiliations.

\begin{tabular}{|l|l|l|l|l|}
\hline Journal : Large 12520 & Article No : 1491 & Pages : 4 & MS Code : 1491 & Dispatch : 3-1-2022 \\
\hline
\end{tabular}


Journal: $\mathbf{1 2 5 2 0}$

Article: 1491

\section{Author Query Form}

Please ensure you fill out your response to the queries raised below and return this form along with your corrections

Dear Author

During the process of typesetting your article, the following queries have arisen. Please check your typeset proof carefully against the queries listed below and mark the necessary changes either directly on the proof/online grid or in the 'Author's response' area provided below

\begin{tabular}{|l|l|l|}
\hline Query & Details Required & Author's Response \\
\hline AQ1 & Please check if the affiliations are captured and presented correctly. & \\
\hline AQ2 & Please check if the keywords are captured and presented correctly. & \\
\hline AQ3 & $\begin{array}{l}\text { Blanc 1928 was mentioned in the manuscript; however, this was not included in the } \\
\text { reference list. }\end{array}$ & \\
\hline AQ4 & Please check captured supplementary materials if correct. & \\
\hline
\end{tabular}

